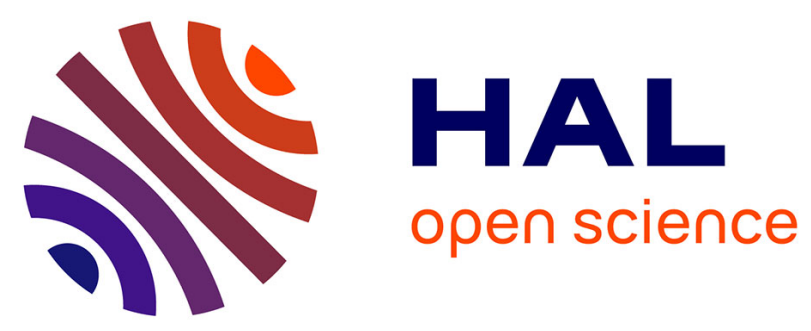

\title{
Photodimerization as an alternative to photocrosslinking of nanoparticles: proof of concept with amphiphilic linear polyoxazoline bearing coumarin unit
}

Laetitia Korchia, Cécile Bouilhac, Vincent Lapinte, Christophe Travelet, Redouane Borsali, Jean-Jacques Robin

\section{To cite this version:}

Laetitia Korchia, Cécile Bouilhac, Vincent Lapinte, Christophe Travelet, Redouane Borsali, et al.. Photodimerization as an alternative to photocrosslinking of nanoparticles: proof of concept with amphiphilic linear polyoxazoline bearing coumarin unit. Polymer Chemistry, 2015, 6 (33), pp.60296039. 10.1039/c5py00834d . hal-01183868

\section{HAL Id: hal-01183868 \\ https://hal.science/hal-01183868}

Submitted on 24 Aug 2015

HAL is a multi-disciplinary open access archive for the deposit and dissemination of scientific research documents, whether they are published or not. The documents may come from teaching and research institutions in France or abroad, or from public or private research centers.
L'archive ouverte pluridisciplinaire HAL, est destinée au dépôt et à la diffusion de documents scientifiques de niveau recherche, publiés ou non, émanant des établissements d'enseignement et de recherche français ou étrangers, des laboratoires publics ou privés. 


\section{Photodimerization as Alternative to Photocrosslinking of Nanoparticles: Proof of concept with Amphiphilic Linear Polyoxazoline Bearing Coumarin Unit}

Laetitia Korchia, ${ }^{a}$ Cécile Bouilhac, ${ }^{a}$ Vincent Lapinte, ${ }^{a^{*}}$ Christophe Travelet, ${ }^{\mathrm{b}, \mathrm{c}}$ Redouane Borsali ${ }^{\mathrm{b}, \mathrm{c}}$ and Jean-Jacques Robin ${ }^{\mathrm{a}}$

\section{Summary}

Photosensitive amphiphilic linear polyoxazolines $\left(\mathrm{CoumC}_{11}-\mathrm{POx}_{\mathrm{n}}\right)$ bearing alkyl chain decorated by a UV-active coumarin end group have been synthesized by cationic ring-opening polymerization (CROP). Using DLS and DOSY NMR experiments, their self-assemblies in water were compared with those of homologous photo-unreactive amphiphilic polyoxazolines $\left.\left(\mathrm{C}_{\mathrm{m}}-\mathrm{POx}\right)_{\mathrm{n}}\right)$. In both cases, spherical nanoparticles with $\mathrm{D}_{\mathrm{H}}$-values around $10 \mathrm{~nm}$ were observed. The CoumC $\mathrm{C}_{11}-\mathrm{POx}_{\mathrm{n}}$ nanoparticles were illuminated upon $\square \square=300 \mathrm{~nm}$ inducing the photedimerization of the coumarin units located in the inner compartment of the nanoparticles. Finally, the pros and the cons of the photo-dimerization of linear copolymers related to the photo-crosslinking of graft copolymers were discussed.

\section{Introduction}

Amphiphilic copolymers have for a long time attracted much attention due to their ability to self-assemble in selective solvents. ${ }^{1-6}$ Otherwise, stimuli-responsive polymeric systems including photo-responsive polymers provide an attractive tool for fabrication of tailored smart functional materials. ${ }^{7}$ Light permits photodimerization, photopolymerization, photocrosslinking, photoisomerization and photoinduced cyclization reactions. ${ }^{8} \mathrm{UV}$ radiation is a simple and convenient form of energy that requires low temperature and inexpensive devices. Moreover the photochemistry is an energy-efficient process, limits the production of wastes and the emission of $\mathrm{v}$

olatile organic compounds (VOC). For these reasons, the photo-process can be classified as an environmentally friendly process. It is specially adapted to biosourced materials and thermally sensitive molecules, as this technology works at ambient temperature. ${ }^{9}$ The photoreaction can be achieved either by cycloaddition of photosensitive molecules (chromophore type) or by polyaddition of activated double bonds ((meth)acrylic monomers) under radical or cationic initiation. In this study, we focus on the 
macromolecules bearing chromophore moieties.

The use of UV irradiation in polymer field concerns the elaboration of soft materials like polymeric micelles and films. In fact, the self-organization in solution of amphiphilic polymers into micelles could occur under UV exposure inducing either by the cross-linking of the shell ${ }^{10}$ or of the core ${ }^{11}$ to control the macromolecular nanoscale size and shape, ${ }^{12}$ to stabilize the assemblies, ${ }^{13}, 14$ to disperse single-walled carbon nanotubes ${ }^{15}$ or the photo-degradation of the micelles to release a drug. ${ }^{16,17}$ The cross-linking of films ${ }^{18}$ or soft materials requires the synthesis of copolymers bearing photosensitive pendant groups able to react under UV exposure and transform free polymeric chain into 3D material. In a few other cases, $\square, \square$-terminated polymers decorated by photosensitive end groups generate photo-cleavable single-chain nanoparticles ${ }^{19}$ or have polymers capable of reversible chain extension. ${ }^{20}$ Several reviews describe $[2+2]$ and $[4+4]$ cycloaddition of the photosensitive moieties giving a cyclobutane dimer under UV exposure. The main photo-reactive chromophores include anthracene, ${ }^{21}$ cinnamic acid, ${ }^{22,} 23$ thymine, stilbene, benzophenone, ${ }^{24}$ dimethylmaleimide ${ }^{25}$ and coumarin. ${ }^{26,27}$ We focus the discussion on the coumarin group which enables both UV light-induced chain cross-linking $(\lambda=320 \mathrm{~nm})$ and chain scission $(\lambda=254 \mathrm{~nm})$ via photodimerization by $[2+2]$ cycloaddition and photocleavage of the chromophore, respectively. ${ }^{19}$ Numerous applications of coumarin have already been described in biology and medicine as therapeutic agents (anti-HIV, ${ }^{28,} 29$ antibacterial, antihyperproliferative, anticoagulant). ${ }^{30}$ They are also used in perfumes and cosmetics, in tobacco or as fluorescent tags and fluoroprobes for instance in herbicide detection. In polymer field, ${ }^{31}$ coumarin was applied in electro-optical applications such as photo-crosslinkable liquid crystalline polymers (LCP) (non-linear optical devices), ${ }^{32}$ in photoactive surface applications where monolayers of liquid crystal polymers bearing coumarin were self-assembled on silicon and quartz, ${ }^{33,34}$ in electroluminescent devices where colors ranged from red to violet by changing the coumarin derivative, in light and energy harvesting applications ${ }^{35}$ and in lithography (Scheme 1). ${ }^{36}$

Otherwise, polyoxazolines (POx) represent valuable bio-inspired polymers with a pseudo-peptidic structure and are considered as an alternative to PEG. To date, they have mainly been investigated towards biomedical applications due to their biocompatibility, biodistribution, blood clearance and protein adsorption. ${ }^{37,38}$ Well-defined POx are easily prepared by the cationic ring-opening polymerization (CROP) of cyclic 2-R-2-oxazolines and various properties are obtained in function of the nature of the $\mathrm{R}$ pendant alkyl chain (Me, Et, Pr, etc.). Many macromolecular architectures based on POx have already been described such as diblock or triblock copolymers bearing hydrophilic and/or hydrophobic 2oxazolines only or obtained by combination with other polymerization process such as CROP-RITP ${ }^{39}$ or 
click reaction between two blocks with terminal reactive end groups. ${ }^{40}$ Graft copolymers were also synthesized from macromonomers ${ }^{41}$ or by click reaction with pendant groups. ${ }^{42}$ These successful syntheses were explained by the numerous possibilities of functionalization of POx using terminating agents ${ }^{43}$ or initiators ${ }^{44}$ as described in several recent reviews. ${ }^{45}$ We can cite our recent work on the association of lipidic derivatives and vegetable oils to POx in order to elaborate amphiphilic LipoPOx. ${ }^{46-}$ 49

Polyoxazolines could be also decorated by photosensitive groups as previously described by David et al. ${ }^{50}$ They copolymerized in dispersion styrene and PMOxmacromers with cinnamoyl end groups to obtain monodisperse micrometer size beads even though no UV study was described in this paper. Hoogenbooom and Dargaville used another strategy with the modification of unsaturated pendant chain of poly(2-(dec-9-enyl)-2-oxazoline) by thiol-ene coupling under UV condition ${ }^{51}$ to crosslink the polymeric materials and form soft gels. Through this example, a photoreaction occurred on POx in the presence of a photoinitiator even though no photosensitive group was bored by it. Inversely Chujo and Saegusa developed the photogelation of POx substituted by either anthracene ${ }^{52,53}$ or coumarin ${ }^{54}$ photosensitive group. These photosensitive polyoxazolines were produced in moderate yields after partially hydrolysis and amidation with coumarin derivative. The anthracene strategy consists in amidation of partially hydrolyzed POx by a derivative bearing both anthracenyl and dithioether moieties. The reversible redox reaction of disulfide groups enabled the interconversion between hydrogel and soluble polymer upon light irradiation.

To our knowledge, the amphiphilic linear POx bearing coumarin in terminal position of the backbone have never been described in the literature. In most cases, the reactive coumarin moieties are located in side-chain. They permit by crosslinking the elaboration of films, or of nano-objects by crosslinking of the micellar core or shell as illustrated in Scheme 1. Crosslinking by photodimerization has been used commercially in the past decade for a wide variety of purposes in paint, printing, adhesive, and dental industries as well as in the field of photoresist. ${ }^{54}$ Herein, we investigated the dimerization of amphiphilic linear polyoxazoline bearing a terminal coumarin unit. Thanks to a preliminary comparison between $\mathrm{C}_{\mathrm{m}}$ $\mathrm{POx}_{\mathrm{n}}$ and CoumC $\mathrm{C}_{11}-\mathrm{POx}_{\mathrm{n}}$, the influence of the coumarin unit on the self-organization in water was examined. Then, the dimerization of the inner part of the nanoparticles was studied in detail by dynamic light scattering and microscopy. 


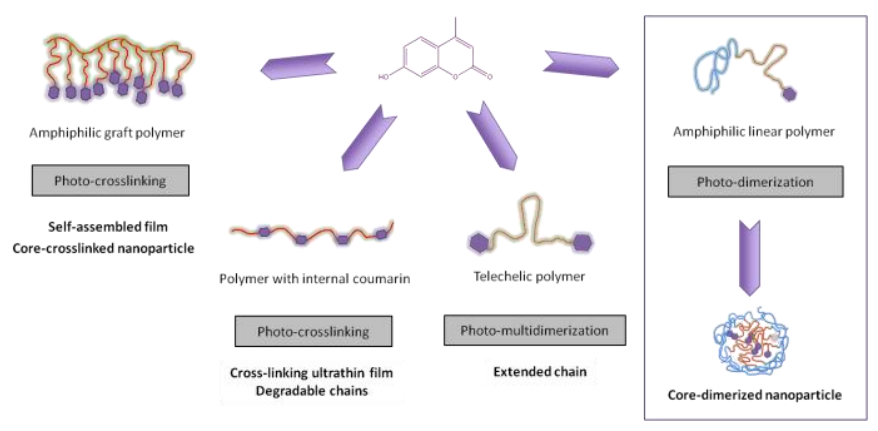

Scheme 1. Overview of the macromolecular architectures containing coumarin unit and their applications.

\section{Results and discussion}

\section{1-Synthesis of amphiphilic linear polyoxazolines}

The amphiphilic diblock polyoxazolines composed of a linear alkyl chain and a hydrophilic block poly(2methyl-2-oxazoline) are named $\mathrm{C}_{\mathrm{m}}-\mathrm{POx}_{\mathrm{n}}$ where $\mathrm{m}$ corresponds to the number of $\mathrm{CH}_{2}$ units in the alkyl chain and $\mathrm{n}$ is the oxazoline monomer unit number. The terminaison step of cationic ring-opening polymerization (CROP) permits the addition of alcohol group at the end of the POx chains. We note that the synthesis of $\mathrm{C}_{\mathrm{m}}-\mathrm{POx}_{\mathrm{n}}$ using alkyl iodide initiator has previously been described by Volet et al. ${ }^{55}$ Futhermore, Winnik described the same structures but 2-ethyl-2-oxazoline or 2-isopropyl-2-oxazoline monomers were replaced by 2-methyl-2-oxazoline. ${ }^{56}$ An alternative structure to $\mathrm{C}_{\mathrm{m}}-\mathrm{PO}_{\mathrm{n}}$ includes the addition of 7-hydroxy-4-methylcoumarin unit at the end of the hydrophobic chain $\left(\mathrm{CoumC}_{11}-\mathrm{POx}_{\mathrm{n}}\right)$. The comparison of these amphiphilic polymers demonstrates the influence of additional UV-active coumarin moieties on the self-assembly of amphiphilic copolymers.

The first step of the $\mathrm{C}_{\mathrm{m}}-\mathrm{POx}_{\mathrm{n}}$ and CoumC $\mathrm{C}_{11}-\mathrm{POx}_{\mathrm{n}}$ synthesis is the preparation of the tosylated initiators from the corresponding alcohols (lauryl alcohol, stearyl alcohol and CoumOH) (Scheme 2). In the last case, a preliminary step is required to modify 7-hydroxy-4-methylcoumarin into $\mathrm{CoumOH}$ after adding $\mathrm{C}_{11}$ extension chain. Finally, $\mathrm{C}_{\mathrm{m}}-\mathrm{POx}_{\mathrm{n}}$ and $\mathrm{CoumC}_{11}-\mathrm{POx}_{\mathrm{n}}$ are synthesized through CROP of 2-methyl-2oxazoline (MOx) in acetonitrile at $80^{\circ} \mathrm{C}$ for 15 hours before the termination step in the presence of methanolic potassium hydroxide.

The modification of 7-hydroxy-4-methylcoumarin into $\mathrm{CoumOH}$ and finally the CROP of MOx was monitored by ${ }^{1} \mathrm{H}$ NMR spectroscopy as illustrated in Figure 1. The tosylation was detected by the appearance of aromatic protons corresponding to Ts group at 7.80, 7.25 and $2.35 \mathrm{ppm}$ as well as by the shift of the $\mathrm{CH}_{2}-\mathrm{O}$ from 3.60 to $3.90 \mathrm{ppm}$. As expected, characteristic signals of the POx block, alkyl chain and coumarin moiety appeared in the ${ }^{1} \mathrm{H}$ NMR spectrum of CoumC ${ }_{11}-\mathrm{POx}_{\mathrm{n}}$. 


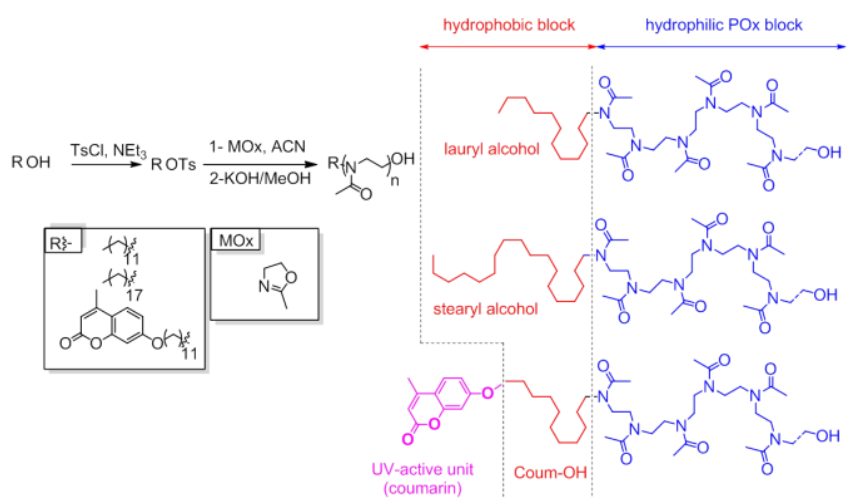

Scheme 2. Synthesis of $\mathrm{C}_{\mathrm{m}}-\mathrm{POx}_{\mathrm{n}}$ and $\mathrm{CoumC}_{11}-\mathrm{POx}_{\mathrm{n}}$ amphiphilic polyoxazolines.

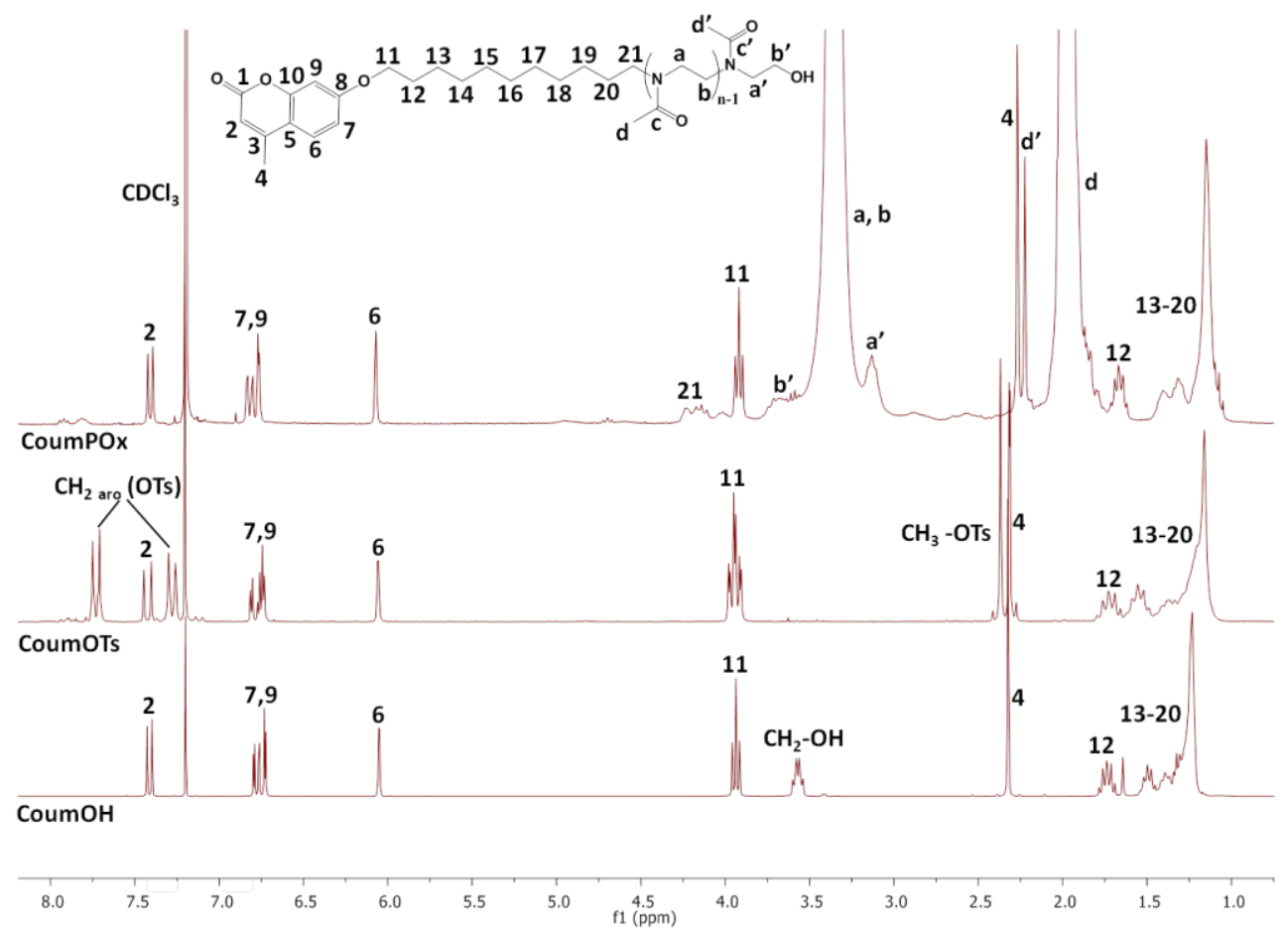

Fig 1. ${ }^{1} \mathrm{H}$ NMR spectra $\left(300 \mathrm{MHz} ; \mathrm{CDCl}_{3}\right)$ of CoumOH, Coum-OTs and CoumC $11-\mathrm{POx}_{\mathrm{n}}$.

For $\mathrm{C}_{\mathrm{m}}-\mathrm{POx}_{\mathrm{n}}$ and $\mathrm{CoumC}_{11}-\mathrm{POx}_{\mathrm{n}}$, various lengths of hydrophilic chain, $\mathrm{n}$ ranging from 12 to 34 , were investigated as compiled in Table 1. The relatively low yields of the CROP, given in the experimental part, were explained by the low molecular weight $\left(\mathrm{M}_{\mathrm{n}}=3000-1000 \mathrm{~g} \mathrm{~mol}^{-1}\right)$ of the POx chains that is reluctant to precipitation phenomenon. The nature of the initiator has little influence on the dispersity of the polymer chains comprised between 1.1 and 1.3 as determined by SEC in DMF. $\mathrm{M}_{\mathrm{PHILE}} / \mathrm{M}_{\mathrm{TOT}}$ ratio corresponding to the molecular weight of the hydrophilic POx related to the total molecular weight of the 
amphiphilic polymer was also reported to bring out the hydrophilic character of all polymers. The percentage of hydrophilic groups per chain varied from 76 to $94 \%$.

Table 1. $\mathrm{C}_{\mathrm{m}}-\mathrm{POx}_{\mathrm{n}}$ and $\mathrm{CoumC}_{11}-\mathrm{POx}_{\mathrm{n}}$ characteristics.

\begin{tabular}{|c|c|c|c|c|}
\hline Copolymers & $\begin{array}{c}\mathrm{M}_{\mathbf{n}}^{\mathrm{a}} \\
{\left[\mathrm{g} \mathrm{mol}^{-1}\right]}\end{array}$ & $\begin{array}{l}\boldsymbol{\oplus}^{\mathbf{a}} \\
{[-]}\end{array}$ & $\begin{array}{c}\mathbf{M}_{\text {PHILE }} / \mathbf{M}_{\text {TOT }}{ }^{b} \\
{[\%]}\end{array}$ & $\begin{array}{c}\mathbf{D}_{\mathbf{H}}^{\mathbf{c}} \\
{[\mathbf{n m}]}\end{array}$ \\
\hline $\mathrm{C}_{12}-\mathrm{POx}_{13}$ & 1200 & 1.16 & 92 & 7.7 \\
\hline $\mathrm{C}_{12}-\mathrm{POx}_{25}$ & 2400 & 1.14 & 88 & 8.4 \\
\hline $\mathrm{C}_{12}-\mathrm{POx}_{33}$ & 2900 & 1.21 & 97 & 7.7 \\
\hline $\mathrm{C}_{18}-\mathrm{POx}_{25}$ & 3300 & 1.23 & 89 & 11.8 \\
\hline CoumC $_{11}-\mathrm{POx}_{13}$ & 1500 & 1.26 & 74 & 9.0 \\
\hline CoumC $_{11}-P^{-} x_{25}$ & 2200 & 1.18 & 96 & 9.9 \\
\hline CoumC $_{11}-\mathrm{POx}_{33}$ & 3200 & 1.30 & 88 & 9.4 \\
\hline
\end{tabular}

a: Determined by SEC in DMF using PMMA standards. ${ }^{b}: \mathrm{M}_{\mathrm{PHILE}} / \mathrm{M}_{\mathrm{TOT}}=85 \mathrm{n} / \mathrm{M}_{\mathrm{n}, \mathrm{GPC}}{ }^{\mathrm{c}}$ : Value $\pm 0.2 \mathrm{~nm}$, determined by DLS technique.

\section{2-Self-organization of $\mathrm{C}_{\mathrm{m}}-\mathrm{POx}_{\mathrm{n}}$ and $\mathrm{CoumC}_{11}-\mathrm{POx}_{\mathrm{n}}$}

To examine the effect of the hydrophobic chains $\left(\mathrm{C}_{12}, \mathrm{C}_{18}\right.$ and $\left.\mathrm{CoumC}_{11}\right)$ on the self-assembly of the corresponding amphiphilic polymers, three candidates in $\mathrm{POx}_{25}$ were investigated: $\mathrm{C}_{12}-\mathrm{POx}_{25}, \mathrm{C}_{18}-\mathrm{POx}_{25}$ and $\mathrm{CoumC}_{11}-\mathrm{POx}_{25}$. Volet et al. have already estimated the $\mathrm{CMC}$ values of $\mathrm{C}_{12}-\mathrm{POx}_{\mathrm{n}}$ and $\mathrm{C}_{18}-\mathrm{POx}_{\mathrm{n}}$ polymers by fluorescence technique and studied the micelles by viscosimetry ${ }^{57}$ and SANS. ${ }^{55}$ Due to the quite pronounced hydrophilic character of the copolymers (Table 1), their self-assembly was studied in aqueous medium (ultrapure Milli-Q water) and the solutions were prepared by direct dissolution of the copolymers at $4 \mathrm{mg} \mathrm{mL}^{-1}$. Preliminary studies have been performed to check the effect of the copolymer concentration on the self-assembly: by DLS, similar $\mathrm{D}_{\mathrm{H}}$-values were measured between 4 and $16 \mathrm{mg} \mathrm{mL}^{-1}$ concentration range (data not shown). When $\mathrm{C}_{\mathrm{m}}-\mathrm{POx}_{\mathrm{n}}$ and $\mathrm{CoumC}_{11}-\mathrm{POx}_{\mathrm{n}}$ were directly dissolved in water, they spontaneously self-assembled as deduced from dynamic light scattering (DLS) measurements. The auto-correlation functions were measured at different angles including 40, 90 and $140^{\circ}$ leading to corresponding relaxation time distributions obtained using CONTIN analysis were reported in Figure $2 .^{58}$ Whatever the scattering angle, the autocorrelation functions $\left(g^{(2)}-1\right)$ exhibit monomodal and quite narrow 
exponential decays. In all cases, the linear dependences of the relaxation frequency $(\Gamma)$ on the square of the wave vector modulus $\left(q^{2}\right)$ clearly indicate the Brownian diffusive motion of particles (Figure 2). The value of the slope is equal to the diffusion coefficient
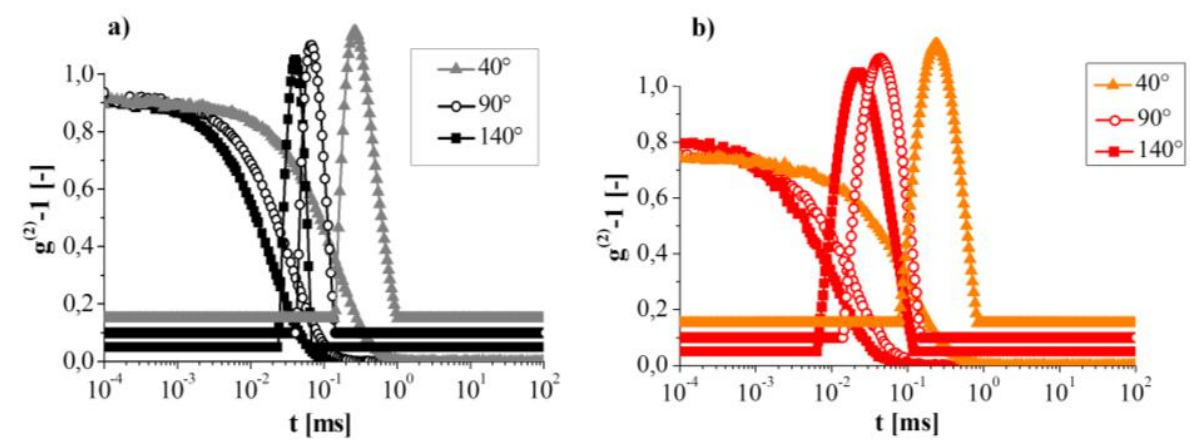

c)
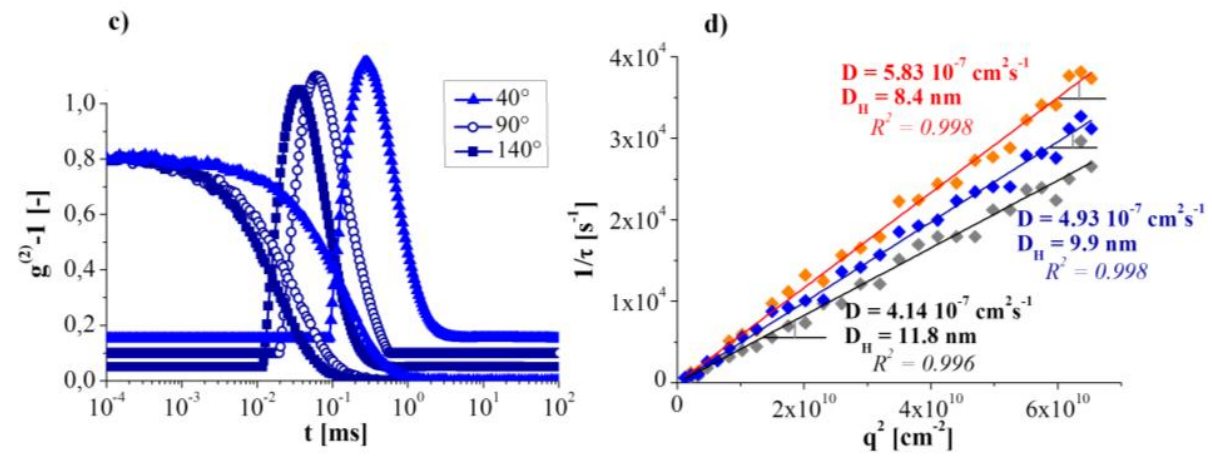

Fig 2. DLS results of (a) $\mathrm{C}_{18}-\mathrm{POx}_{25}$, (b) $\mathrm{C}_{12}-\mathrm{POx}_{25}$ and (c) CoumC $11-\mathrm{POx}_{25}$ directly dissolved at $4 \mathrm{mg} \mathrm{mL}^{-}$ 1

in water. $(a, b, c)$ : autocorrelation function $\left(g^{(2)}-1\right)$ as a function of time $(t)$ and relaxation time distribution at scattering angles of 40,90 and $140^{\circ}$, and (d) dependence of $\Gamma$ on $\mathrm{q}^{2}$ from 15 up to $150^{\circ}$ by step of $\quad 5^{\circ}$ (coefficient of determination for the linear regression $\left.\left(\mathrm{R}^{2}\right)\right)$. $(D)$ of the particles from which the hydrodynamic diameter $\left(\mathrm{D}_{\mathrm{H}}\right)$ is calculated using the Stokes-Einstein relation (Equation 1):

$D_{H}=\frac{k_{B} T}{3 \pi \eta_{0} D}$

where $k_{B}$ is the Boltzmann constant, $T$ represents the absolute temperature of the sample and $\eta_{0}$ is the viscosity of the pure solvent (water in this case). ${ }^{59,60}$

The calculated values of $\mathrm{D}_{\mathrm{H}}$ are 8.4 and $11.8 \mathrm{~nm}$ for $\mathrm{C}_{12}-\mathrm{POx}_{25}$ and $\mathrm{C}_{18}-\mathrm{POx}_{25}$, respectively, and $9.9 \mathrm{~nm}$ for $\mathrm{CoumC}_{11}-\mathrm{POx}_{25}$. Indeed, whatever the scattering angle, the relaxation time decreases as follows $\tau_{\mathrm{C} 18-}$ 
POx25 $>\tau_{\text {CoumC11-POx25 }}>\tau_{\mathrm{C} 12-\mathrm{POx} 25}$, reflecting the lower diffusion coefficients calculated for $\mathrm{C}_{18}-\mathrm{POx}_{25}$ and $\mathrm{CoumC}_{11}-\mathrm{POx}_{25}$.

In order to go deeper in the meaning of the results, DLS experiments were carried out in acetone, a good organic solvent for both alkyl and polyoxazoline blocks. For CoumC $\mathrm{Cl}_{11}-\mathrm{POx}_{25}$, a $\mathrm{D}_{\mathrm{H}}$-value of $2.6 \mathrm{~nm}$ corresponding to an isolated single-polymer chain was measured (data not shown). This value seems consistent with the one of persistence length $l_{P}=2.0 \mathrm{~nm}$ previously calculated for the polyoxazoline chain and considered as a semi-flexible molecule by Volet et al. ${ }^{55}$ We note that the notion of persistence length is strongly correlated to worm-like chain model ${ }^{61,62}$ valid for semi-flexible polymers in dilute solution and could be used to estimate (although the molar mass is low) the mean-square diameter of gyration $\left(\mathrm{D}_{\mathrm{G}}\right)$ according to Equation 2:

$D_{G}^{2}=\frac{4 l_{P} L_{C}}{3}-4 l_{P}^{2}+\frac{8 l_{P}^{3}}{L_{C}}-\frac{8 l_{P}^{4}}{L_{C}^{2}}\left[1-\exp \left(-\frac{L_{C}}{l_{P}}\right)\right]$

where $L_{c}$ designates the contour length. For $n=25$, making the hypotheses that the whole polymer chain behaves as the semi-flexible hydrophilic block and can be viewed as an alkyl chain with 16 carbon atoms (vide infra) (thus $n_{\text {apparent }}=25+(16 / 3) \approx 30$ ), we get $L_{c}=10.2 \mathrm{~nm}$ and $\mathrm{D}_{\mathrm{G}}=4.0 \mathrm{~nm}$. Based on a $\mathrm{D}_{\mathrm{H}}$-value of $2.6 \mathrm{~nm}$, a ratio $\rho=\mathrm{D}_{\mathrm{G}} / \mathrm{D}_{\mathrm{H}}=4.0 / 2.6=1.5$ was calculated meaning the presence of monodisperse random coils made of a single linear chains in a theta solvent.

In contrast to DLS measurements performed in acetone, CoumC $\mathrm{C}_{11}-\mathrm{POx}_{\mathrm{n}}$ exhibits in aqueous medium $\mathrm{D}_{\mathrm{H}^{-}}$ values of about $10 \mathrm{~nm}$, which implies that single unimers are not present in water and that the copolymer chains are able to self-assemble into nanoparticles with size up to $11.8 \mathrm{~nm}$ (Figure 3 ). In addition, this result shows that the system is not compatible with the simple star-like micelle model ${ }^{63}$ for which the characteristic expected diameter would be roughly $2 L_{C}=20.4 \mathrm{~nm}$. The $\mathrm{D}_{\mathrm{H}^{-}}$-values of other amphiphilic polymers, $\mathrm{C}_{12}-\mathrm{POx}_{25}$ and $\mathrm{C}_{18}-\mathrm{POx}_{25}$, are also reported in Figure 3. 


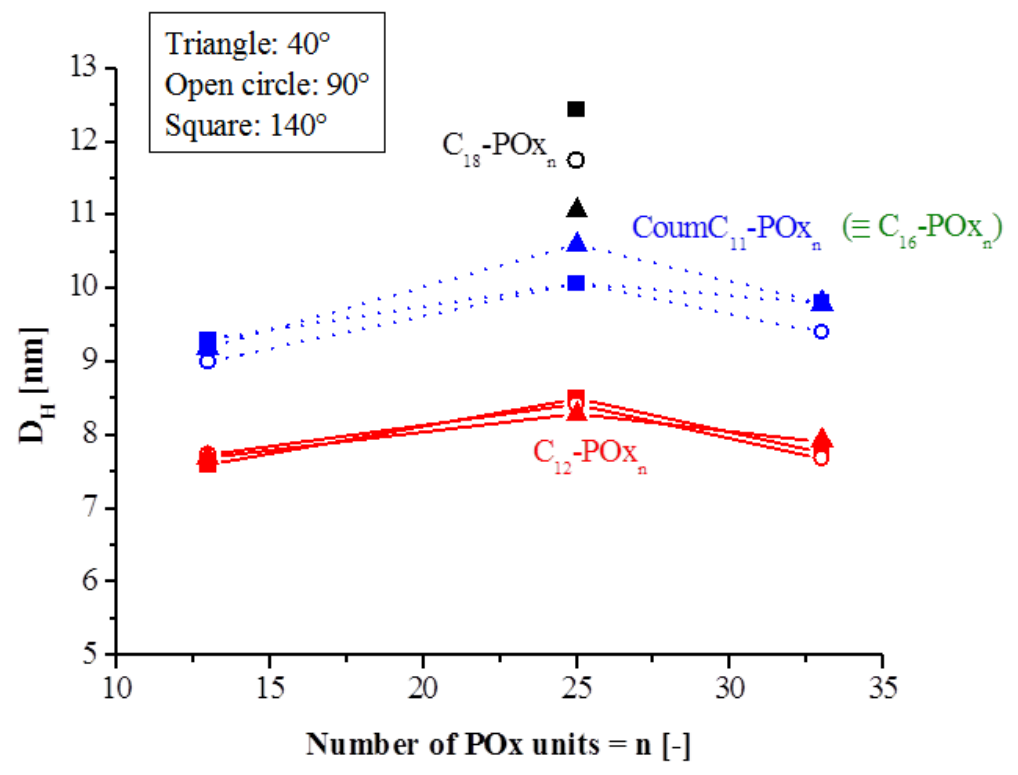

Fig 3. Hydrodynamic diameter $\left(D_{H}\right)$ determined using DLS as a function of the length of POx block for $\mathrm{C}_{18}-\mathrm{POx}_{\mathrm{n}}, \mathrm{C}_{12}-\mathrm{POx}_{\mathrm{n}}$ and $\mathrm{CoumC}_{11}-\mathrm{POx}_{\mathrm{n}}\left(\right.$ direct dissolution in water at $4 \mathrm{mg} \mathrm{mL} \mathrm{L}^{-1}$ ).

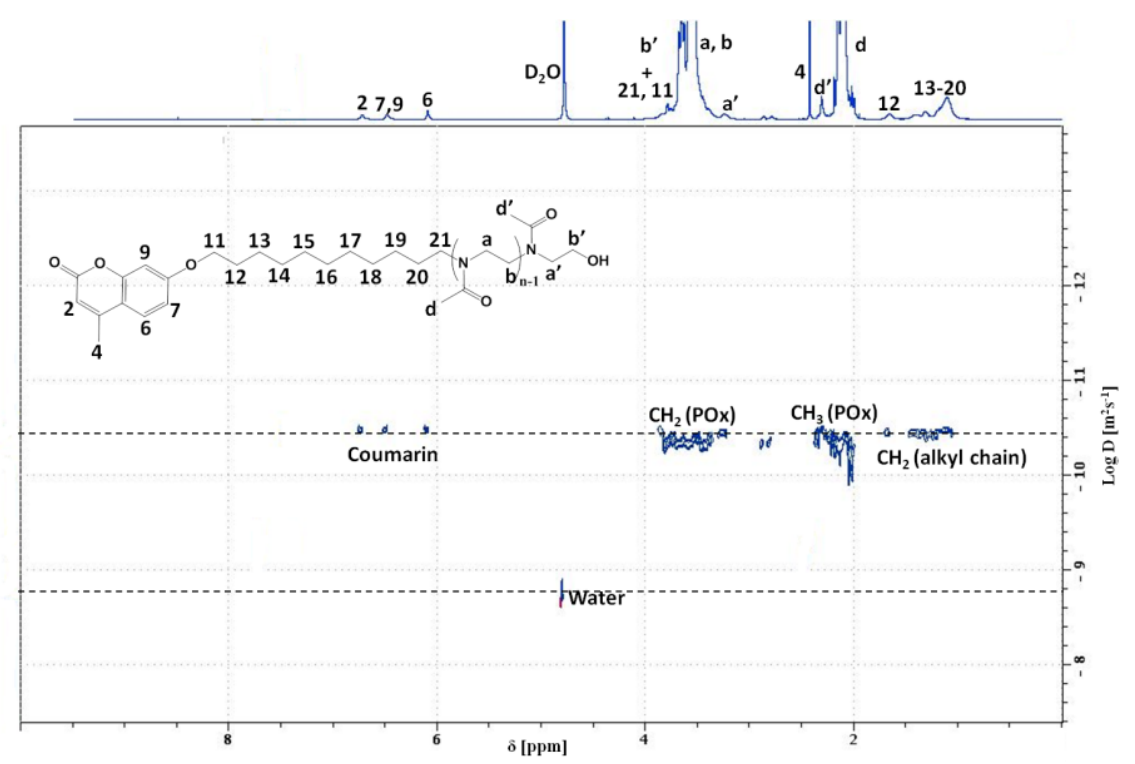

Fig 4. ${ }^{1} \mathrm{H}$ DOSY NMR spectrum $\left(600 \mathrm{MHz} ; \mathrm{D}_{2} \mathrm{O}\right)$ of CoumC $\mathrm{C}_{11}-\mathrm{POx}_{25}$ dissolved in water at $11.7 \mathrm{mg} \mathrm{mL}^{-1}$.

The copolymers differ not only by the length of their hydrophilic blocks but also by the size and nature of their hydrophobic parts (12 carbon atoms for $\mathrm{C}_{12}-\mathrm{POx}_{\mathrm{n}}, 18$ for $\mathrm{C}_{18}-\mathrm{POx}_{\mathrm{n}}$ and 11 carbon atoms end-capped by a coumarin group for CoumC $\left.\mathrm{C}_{11}-\mathrm{POx}_{\mathrm{n}}\right)$. For a given hydrophobic block, it clearly appears that the $\mathrm{D}_{\mathrm{H}^{-}}$ values do not increase linearly with $n$ but reach a maximum for $n=25$ and a similar value for $\mathrm{C}_{12}-\mathrm{POx}_{13}$ and $\mathrm{C}_{12}-\mathrm{POx}_{33}$. The same trend was observed for CoumC $\mathrm{C}_{11}-\mathrm{POx}_{\mathrm{n}}$ series. The size differences does not 
exceed $10 \%$. Therefore, the length of the hydrophilic block has a poor influence on the size of the selfassembly of the copolymers in water. Several explanations can be given including the extension of the polyoxazoline chains in water and/or their low compactness. Besides, the contrast polymer/solvent may be not favorable under the experimental conditions. A similar behaviour has already been evidenced in a previous work on polyoxazoline-based copolymers. ${ }^{49}$

The size of the self-assemblies was more sensitive to the hydrophobic block. Note that due to the cyclic character of the coumarin group, we hypothesized that the $\mathrm{CoumC}_{11^{-}} \mathrm{POx}_{\mathrm{n}}$ copolymers amount to $\mathrm{C}_{16^{-}}$ POx $x_{n}$ copolymers. The $\mathrm{D}_{\mathrm{H}^{-}}$values increase with the length of the hydrophobic block. For instance, in the $\mathrm{POx}_{25}$ series, $\mathrm{D}_{\mathrm{H}}$ increases from 8.4, 9.9 to $11.8 \mathrm{~nm}$ for $\mathrm{C}_{12}-\mathrm{POx}_{25}$, CoumC $\mathrm{Cl}_{11}-\mathrm{POx}_{25}\left(\right.$ i.e. $\left.\mathrm{C}_{16}-\mathrm{POx}_{25}\right)$ and $\mathrm{C}_{18}-\mathrm{POx}_{25}$, respectively. More precisely, the $\mathrm{D}_{\mathrm{H}}$-values increase by $40 \%$ when the number of carbon of the hydrophobic block increases by $50 \%$. The higher characteristic sizes observed for CoumC ${ }_{11}-\mathrm{POx}_{\mathrm{n}}($ i.e. $\left.\mathrm{C}_{16}-\mathrm{POx}_{\mathrm{n}}\right)$ and $\mathrm{C}_{18}-\mathrm{POx}_{25}$ in water may be explained by the necessity of having a higher aggregation number in order to assure an efficient stabilization by the hydrophilic block. ${ }^{49}$ The sizes of the selfassemblies are mainly controlled by the hydrophobic block length. Lastly, note that the characteristic size of the nanoparticles remains reasonably unchanged when varying the scattering angle (Figure 3), which implies that the systems are relatively monodisperses.

So as to apprehend more closely and more finely the self-assembling behavior of CoumC $11-\mathrm{POx}_{25},{ }^{1} \mathrm{H}$ diffusion ordered spectroscopy NMR $\left({ }^{1} \mathrm{H}\right.$ DOSY NMR) was performed in $\mathrm{D}_{2} \mathrm{O}$ as shown in Figure 4. ${ }^{64-66}$ It is noteworthy that this technique is appropriate for the diffusion coefficients such as $10^{-12} \leq \mathrm{D} \leq 2 \times 10^{-}$ ${ }^{3} \mathrm{~m}^{2} \mathrm{~s}^{-1}$, 66 corresponding to $\mathrm{D}_{\mathrm{H}^{-}}$values lower than $c a .490 \mathrm{~nm}$ which is the case of $\mathrm{CoumC}_{11}-\mathrm{POx}_{\mathrm{n}}$ nanoparticles measured by DLS. Almost all the spots belonged to CoumC ${ }_{11}-\mathrm{POx}_{25}$ hydrogen atoms and they were aligned to a unique horizontal line at a $\mathrm{D}=4.57 \times 10^{-11} \mathrm{~m}^{2} \mathrm{~s}^{-1}$ corresponding to $\mathrm{D}_{\mathrm{H}}$ of $10.7 \mathrm{~nm}$. Moreover, the spot at a higher diffusion coefficient value was reasonably attributed to free water molecules $(\delta=4.8 \mathrm{ppm}) .{ }^{67} \mathrm{~A}$ similar spectrum was recorded in $\mathrm{D}_{2} \mathrm{O}$ for $\mathrm{C}_{12}-\mathrm{POx}_{24}$ (see SI) giving a translational diffusion coefficient $\left(\mathrm{D}=6.8 \times 10^{-11} \mathrm{~m}^{2} \cdot \mathrm{s}^{-1}\right)$ and a $\mathrm{D}_{\mathrm{H}}$-value of $7.4 \mathrm{~nm}$. In both cases, these results are in good agreement with those determined by DLS (Table 1) and confirm the self-assembly behavior of the copolymers in water.

\section{3-Photo-dimerisation of self-assembled CoumC $\mathrm{C1}_{11}-\mathrm{POx}_{\mathrm{n}}$}

With regards to coumarinated polyoxazoline, CoumC $_{11}-\mathrm{POx}_{\mathrm{n}}$, a self-organization in water into nanoparticles constituted of a hydrophobic inner part composed of alkyl chains linked to a coumarin unit surrounded by a hydrophilic polyoxazoline chains was observed. The chromophores located in the 
nanoparticle inner part were dimerized under one hour of UV exposure at $\lambda=300 \mathrm{~nm}$ as illustrated in Scheme 3.

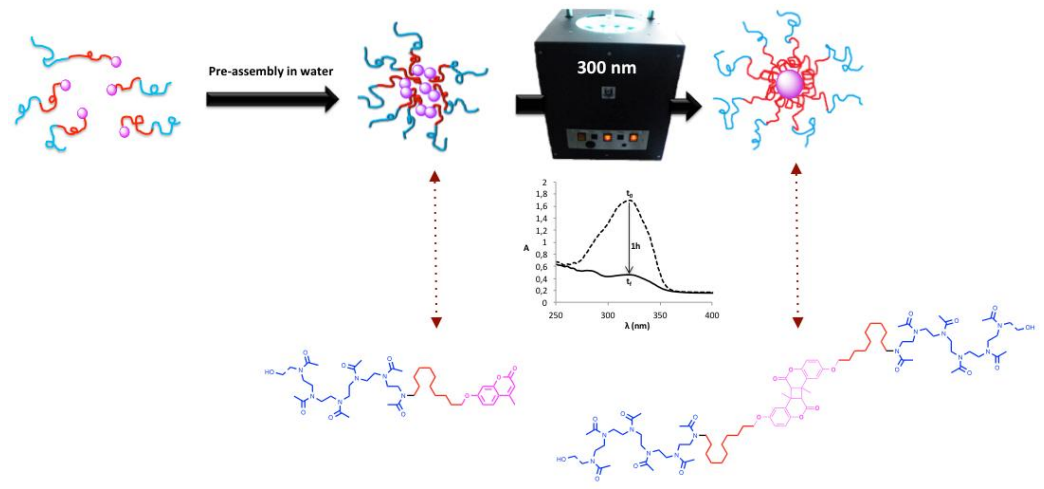

Scheme 3. Principle of the photo-dimerization of self-organized CoumC $11-\mathrm{POx}_{\mathrm{n}}$.

CoumC $_{11}-\mathrm{POx}_{\mathrm{n}}$ in water were studied by DLS at various scattering angles before (Figure $2 \mathrm{c}$ ) and d)) and after UV-illumination (Figure 5). Whatever the scattering angle, the relaxation time distributions obtained from the autocorrelation functions exhibit, for all the systems, a bimodal exponential decay after UVirradiation. They are shown at scattering angles of 40,90 and $140^{\circ}$ as illustrated for CoumC $11-\mathrm{POx}_{25}$ in Figure 5.

a)

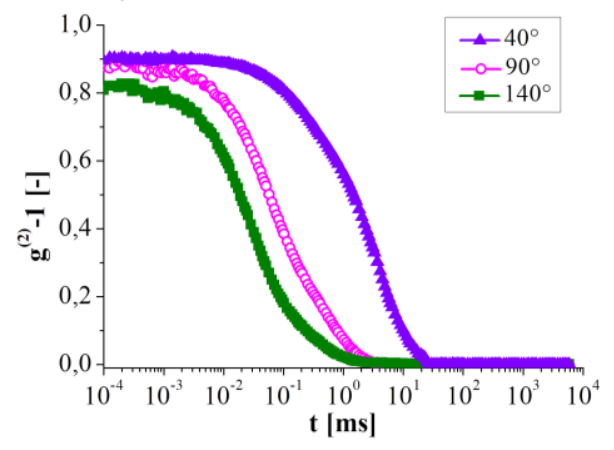

c) b)

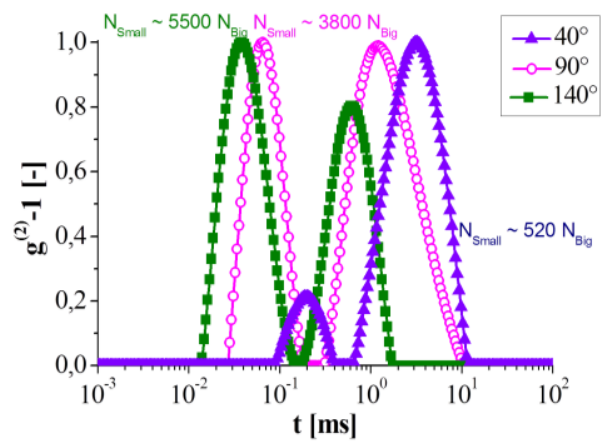

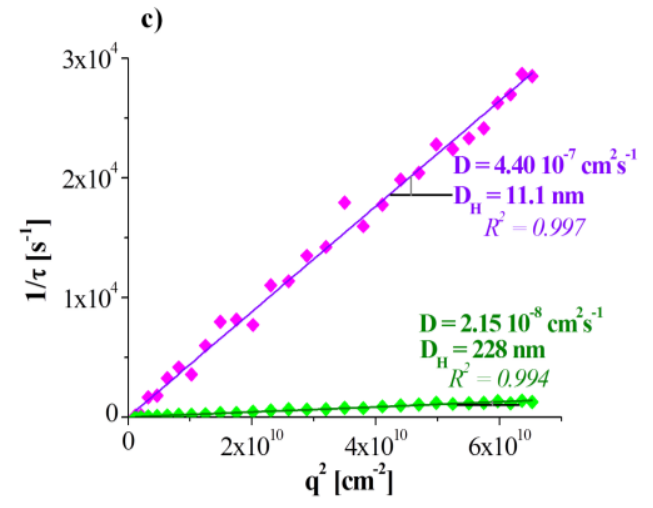


Fig 5. DLS results of CoumC $11-\mathrm{POx}_{25}$ directly dissolved at $4 \mathrm{mg} \mathrm{mL}^{-1}$ in water after UV-irradiation. (a, b) autocorrelationfunction $\left(\mathrm{g}^{(2)}-1\right)$ as a function of time $(\mathrm{t})$ and relaxation time distribution at scattering angles of 40,90 and $140^{\circ}$, and (c) dependence of $\Gamma$ on $\mathrm{q}^{2}$ from 15 up to $150^{\circ}$ by step of $5^{\circ}$ (coefficient of determination for the linear regression $\left(\mathrm{R}^{2}\right)$ ).

Two distributions in size of nanoparticles co-existed with calculated $\mathrm{D}_{\mathrm{H}^{-}}$-values of 11.1 and $228 \mathrm{~nm}$. The lower value is close to the size of the nanoparticles measured before UV-irradiation (i.e. 9.9 nm). After $\mathrm{UV}$-irradiation, the appearance of bigger nanoparticles may originate from inter-particulate aggregations between smaller nanoparticles due to covalent binding via dimerization of coumarin groups belonging to different primary structures or to weak interactions ( $\pi-\pi$ interactions) between the self-assemblies. As expected, the bigger nanoparticles are predominant at low scattering angles. However, the fact that the slow relaxation mode (i.e. right hand side peak) has a surface area comparable (especially at $90^{\circ}$ ) with the one of the fast relaxation mode (i.e. left hand side peak) does not mean that an equal number of small and big nanoparticles are present. Indeed, DLS measurements are much more sensitive to the bigger objects than small ones. ${ }^{68}$ Assuming that the present nanoparticles behave like hard-spheres in water and that all the nanoparticles have the same density, the percentage of small nanoparticles can be calculated using Equation 3:

$\frac{N_{\text {Small }}}{N_{\text {Big }}}=\left(\frac{\tau_{\text {Big }}}{\tau_{\text {Small }}}\right)^{3}\left(\frac{S_{\text {Sma } l l}}{S_{\text {Big }}}\right)$

where $N_{\text {Small }}$ refers to the number of small nanoparticles (fast relaxation mode), $\tau_{\text {Small }}$ is the relaxation time corresponding to the small nanoparticles and $S_{\text {Small }}$ represents the surface area under the peak related to the small nanoparticles. ${ }^{49,59}$ For example at $90^{\circ}$, we have $\mathrm{S}_{\text {Small }}=0.492$ a. u., $\mathrm{S}_{\mathrm{Big}}=0.835$ a. u., $\tau_{\text {Small }}=$ $0.06524 \mathrm{~ms}$ and $\tau_{B i g}=1.215 \mathrm{~ms}$. Thus, we get $\mathrm{N}_{\text {Small }} \sim 3800 \mathrm{~N}_{\text {Big. }}$. Therefore, the small nanoparticles represent $99.97 \%$ of the nanoparticles in number.

The $\mathrm{D}_{\mathrm{H}}$-values of the coumarin end-capped copolymers self-assemblies in water before and after UVirradiation, calculated from the particle diffusion coefficients using the Stock-Einstein equation, are collected in Figure 6. 


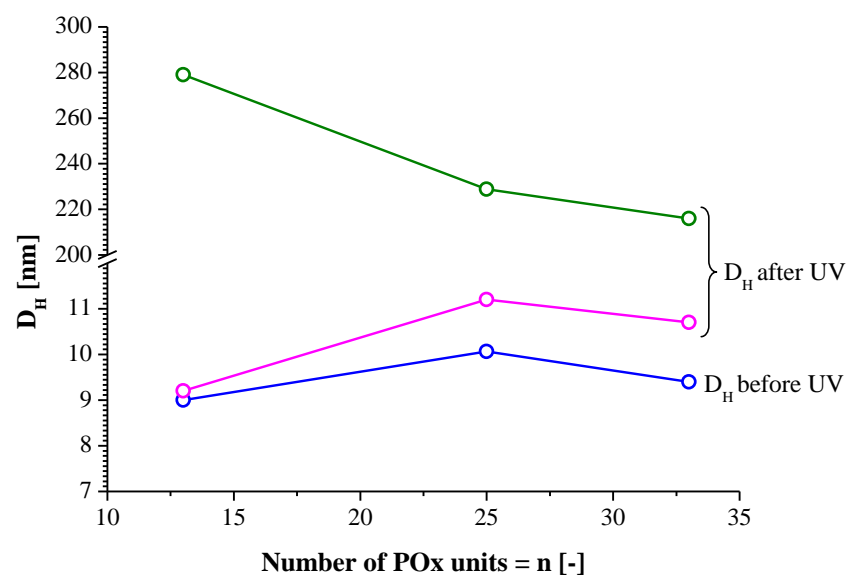

Fig 6. Hydrodynamic diameter $\left(D_{H}\right)$ determined using DLS as a function of the length of the POx block for CoumC $_{11}-\mathrm{POx}_{\mathrm{n}}$ before and after UV-irradiation (direct dissolution in water at $4 \mathrm{mg} \mathrm{mL}^{-1}$ ).

As already mentioned, after UV-irradiation, twbo distributions in size of nanoparticles were observed by DLS. It is noteworthy that the evolution of the lowest $\mathrm{D}_{\mathrm{H}}$-values as a function of $\mathrm{n}$ follows a similar profile than the copolymer self-assemblies before UV-irradiation. Besides, the size of the small nanoparticles, observed after UV-irradiation, remains close to the starting ones with a maximum increase of only $14 \%$ for CoumC $_{11}-\mathrm{POx}_{33}$. This relative difference tends to increase with the length of the hydrophilic block (from 2 to $14 \%$ for $\mathrm{n}=13$ to 33). The copolymer with short polyoxazoline block $\left(\right.$ CoumC $\left._{11}-\mathrm{POx}_{13}\right)$ is less hydrophilic than CoumC $\mathrm{C}_{11}-\mathrm{POx}_{25}$ and $\mathrm{CoumC}_{11}-\mathrm{POx}_{33}$, (76\% versus 86 and $89 \%$, respectively - Table 1) and, consequently, has lower chain mobility within the self-assemblies in aqueous solution. The system is more confined and the inner part of the nanoparticles is more compact, limiting the possible re-organizations. With such frozen systems, the UV-irradiation may have a very limited impact on the $\mathrm{D}_{\mathrm{H}^{-}}$-values of the copolymer self-assemblies. More hydrophilic systems $\left(\mathrm{CoumC}_{11^{-}}\right.$ $\mathrm{POx}_{25}$ and $\mathrm{CoumC}_{11}-\mathrm{POx}_{33}$ ) may have a lower compactness enabling, to a certain extent, some mobility or re-organization of the copolymers within the suspended nanoparticles in water, especially under UVirradiation. A slight increase of the size of the primary self-assemblies is observed in this case, accompanied by an increase of the aggregation number $\left(\mathrm{N}_{\mathrm{Agg}}=41\right.$ before UV versus 65 after UV, vide infra). However, note that this phenomenon is not proportional to the hydrophilic percentage of the copolymers.

Regarding the bigger nanoparticles formed after UV-irradiation, the characteristic size decreases when the length of the polyoxazoline block increases (from $279 \mathrm{~nm}$ for $\mathrm{n}=13$ to $216 \mathrm{~nm}$ for $\mathrm{n}=33$ ). The highest $\mathrm{D}_{\mathrm{H}}$-value measured for the copolymer with the shorter polyoxazoline chain $\left(\mathrm{CoumC}_{11}-\mathrm{POx}_{13}\right)$ may be linked to the fact that, at a constant mass concentration, numerous chains are present when $\mathrm{n}$ is small. 
This implies that more coumarin end-groups are available in the system, which statistically increases the possibility of having coumarin-groups located in the outer part of the primary nanoparticles. Consequently, covalent binding via dimerization of coumarin groups belonging to different primary nanoparticles (provoking the sticking of several of them) is promoted! The access of the inner part of the nanoparticles may be easier with shorter polyoxazoline chains, which promotes inter-particles binding. The aggregation number $\left(\mathrm{N}_{\mathrm{Agg}}\right)$ of the nanoparticles before and after UV-irradiation, in the case of CoumC $\mathrm{C}_{11}-\mathrm{POx}_{25}$, was deduced by a Zimm-like plot $^{57}$ after angular extrapolation towards small angles and at a given concentration $\left(\mathrm{dn} / \mathrm{dC}=0.2773 \mathrm{~mL} \mathrm{~g}^{-1}\right.$ ) (data not shown). After extrapolation towards 0 , the apparent mass-average molecular weight $\left(\mathrm{M}_{\mathrm{w}, \mathrm{app}}\right)$ was equal to $1.02 \times 10^{5} \mathrm{~g} \mathrm{~mol}^{-1}$ before $\mathrm{UV}$, and after UV-irradiation to $1.61 \times 10^{5} \mathrm{~g} \mathrm{~mol}^{-1}$ for the primary nanoparticles and $4.21 \times 10^{6} \mathrm{~g} \mathrm{~mol}^{-1}$ for the big ones, implying $\mathrm{N}_{\mathrm{Agg}}$ of $c a .41,65$ and 1706, respectively.

AFM imaging technique was performed on $\mathrm{CoumC}_{11}-\mathrm{POx}_{25}$ before and after UV-irradiation (Figure 7). Individual and well-defined nanoparticles with spherical shape were observed on the substrate. Statistical treatment carried out on more than 100 objects gave a main height $\left(\mathrm{H}_{\mathrm{AFM}}\right.$, MAX $)$ of $6.5 \mathrm{~nm}$ before UVirradiation. After UV-irradiation, a main height of $6 \mathrm{~nm}$ was observed together with one secondary maximum at $22 \mathrm{~nm}$.

$\mathrm{H}_{\mathrm{AFM}}$, MAX obtained before UV-irradiation is in good agreement with the $\mathrm{D}_{\mathrm{H}}$ of $9.9 \mathrm{~nm}$ measured by DLS. As expected, the DLS size is higher due to the swollen state of the self-assemblies in the presence of the solvent. Similar results were obtained after UV-irradiation for the small nanoparticles. Regarding the bigger objects corresponding to the secondary maximum height of $22 \mathrm{~nm}$, this value is more than 10 times lower than the $\mathrm{D}_{\mathrm{H}}$-value found by DLS $\left(\mathrm{D}_{\mathrm{H}}=228 \mathrm{~nm}\right)$. This difference may be due to a considerable shrinking upon drying of the self-assemblies. It may also be explained by an important subsidence of the big nanoparticles due to a weaker mechanical resistance in the unswollen state. Besides, it is worth noting that the secondary maximum height, observed in the histogram of AFM images after $\mathrm{UV}$-irradiation, corresponds approximately to the quadruple size of the primary nanoparticles of $\mathrm{H}_{\mathrm{AFM}}$, $\operatorname{MAX}=6 \mathrm{~nm}$. This suggests that the bigger nanoparticles may originate from the coalescence of four small nanoparticles. The coalescence may be due to covalent bindings via coumarin-groups or more likely weaker interactions including coumarin-polyoxazoline or polyoxazoline-polyoxazoline. The last hypothesis doesn't seem valuable since after one hour of UV illumination of $\mathrm{C}_{12}-\mathrm{POx}_{25}$, no aggregation was observed. Moreover, the coumarin-coumarin interactions across the hydrophilic POx corona appeared unlikely. The In brief, the amphiphilic linear polymers seem to be relevant macromolecular structures to obtain nanoparticles with photo-active inner part. Moreover, the synthesis of these polymers 
offers several advantages related to amphiphilic graft copolymers: i) elaboration of similar selforganizations using oligomers instead of high molecular weight polymers, ii) easy control of the hydrophilic-hydrophobic balance of the small polymers, iii) the end chain functionalization of polymers is compatible with various polymerization processes including radical polymerization, ionic polymerization such as CROP whereas the synthesis of graft copolymers is limited to radical polymerization with (meth)acrylate monomers, and iv) this synthetic pathway is versatile since amphiphilic linear copolymers can be synthesized using hydrophobic and hydrophilic comonomers as well as using antagonist monomers and macroinitiator (hydrophobic and hydrophilic and vice versa).
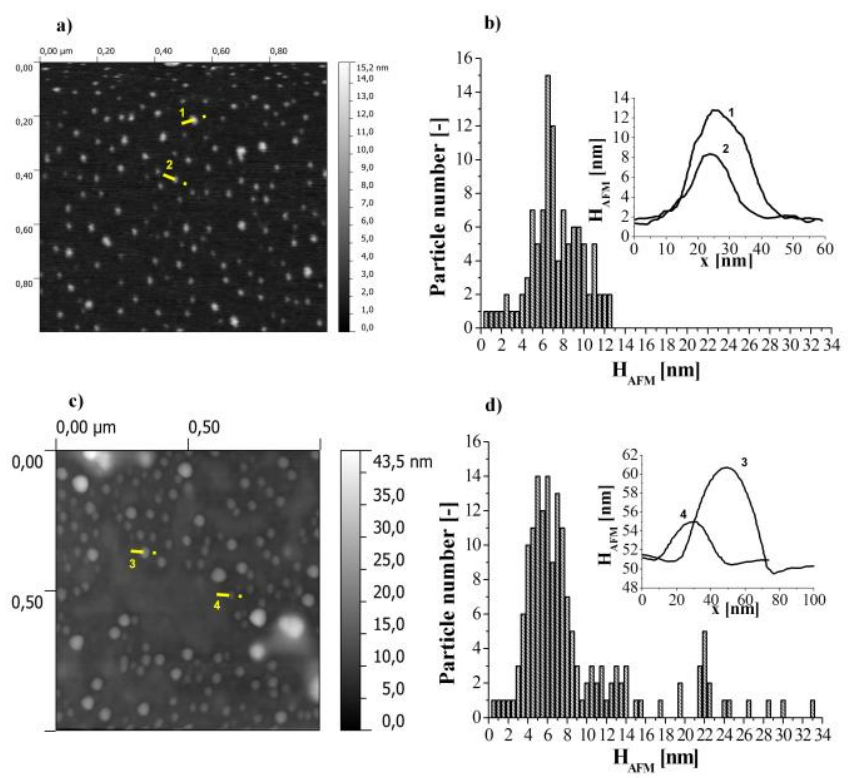

Fig 7. AFM topographic image in tapping mode using a monolithic silicon tip (a) before and (c) after UVirradiation, and corresponding height $\left(\mathrm{H}_{\mathrm{AFM}}\right)$ distribution after baseline correction over more than 100 self-assemblies (b) before and (d) after UV-irradiation and in inset associated topographic cross-section profile corresponding to the yellow line on the topographic images for CoumC ${ }_{11}-\mathrm{POx}_{25}$ at $0.08 \mathrm{mg} \mathrm{mL}^{-1}$ in water dropped onto silica wafer. 


\section{Experimental}

\section{Materials}

2-Methyl-2-oxazoline (MOx) was dried and distilled from $\mathrm{CaH}_{2}$ and stored under dry nitrogen atmosphere. Acetonitrile (ACN) was distilled before use and stored under dry nitrogen. 7-Hydroxy-4methylcoumarin, 11-bromoundecanol, lauryl alcohol, stearyl alcohol, ether, chloroform, ethanol, methanol, $p$-toluenesulfonyl chloride $(\mathrm{TsCl})$, triethylamine $\left(\mathrm{Et}_{3} \mathrm{~N}\right)$, pyridine, $\mathrm{MgSO}_{4}$, potash $(\mathrm{KOH})$ and potassium carbonate $\left(\mathrm{K}_{2} \mathrm{CO}_{3}\right)$ were used without further purification. Dialysis membranes Spectra/Por ${ }^{\circledR}$ MWCO 500-800 were purchased from Spectrum Laboratories, Inc.

\section{Measurements}

Nuclear magnetic resonance (NMR) spectra were recorded on a NMR BrukerAvance I $300 \mathrm{MHz}$ or on a BrukerAvance III $600 \mathrm{MHz}$ spectrometers. The chemical shifts were in part per million (ppm), where (s) means a singlet, (d) a doublet, (t) a triplet, (m) a multiplet and (dd) a doublet of doublet. Chemical shifts $\left({ }^{1} \mathrm{H} \mathrm{NMR}\right)$ were referenced to the peak of residual $\mathrm{CHCl}_{3}$ at $7.26 \mathrm{ppm}$. Chemical shifts $\left({ }^{13} \mathrm{C}\right.$ NMR $)$ were referenced to $\mathrm{CDCl}_{3}$ at $77 \mathrm{ppm}$. Diffusion-ordered NMR spectroscopy (DOSY) experiments were performed on a BrukerAdvance 3 at $20{ }^{\circ} \mathrm{C}$ in $2.5 \mathrm{~mm}$ microtubes operating at $600 \mathrm{MHz}$ with $\mathrm{D}_{2} \mathrm{O}$ as solvent. The software used was Topspin 2.1 using the exponential method with a logarithmic scale. Size exclusion chromatography (SEC) was performed on a Spectra-Physics apparatus equipped with an RI Shodex refractive index detector. Two PL-gel mix C columns were used at $70{ }^{\circ} \mathrm{C}$ with a $0.8 \mathrm{~mL} / \mathrm{min}$ flow rate of DMF (0.1\% LiBr), calibrated using poly(methylmethacrylate) standards. Dynamic light scattering (DLS) measurements were performed using an ALV/CGS-8FS/N069 apparatus (from ALV) equipped with an ALV/LSE-5004 multiple $\tau$ digital correlator with a $125 \mathrm{~ns}$ initial sampling time (from ALV) and a $35 \mathrm{~mW}$ red HeNe linearly polarized laser operating at a wavelength of $632.8 \mathrm{~nm}$ (from JDSU). The copolymer suspensions in water (direct copolymer dissolution in Milli-Q water - characterized by a resistivity of $18.2 \mathrm{M} \Omega \mathrm{cm}$ - at a concentration of $4 \mathrm{mg} \mathrm{mL}^{-1}$ ) were successively filtered through 0.45 and then $0.1 \mu \mathrm{m}$ hydrophilic PTFE syringe filters (from Millipore and Whatman, respectively), loaded in $10 \mathrm{~mm}$ diameter cylindrical cells and maintained at a constant temperature of $25.0 \pm 0.1{ }^{\circ} \mathrm{C}$ prior to measurement. Data were collected at different scattering angles ranging from 20 to $154^{\circ}$ (i.e. $4.59 \times 10^{-}$ ${ }^{3} \leq \mathrm{q}=(4 \pi \mathrm{n} / \lambda) \sin (\theta / 2) \leq 2.58 \times 10^{-2} \mathrm{~nm}^{-1}$ in pure water where $\mathrm{q}$ represents the squattering vector modulus, $\mathrm{n}$ the refractive index of the pure solvent (water in this case), $\lambda$ the wavelength of the incident light in vacuo and $\theta$ the scattering angle relative to the transmitted beam) by a step of $1^{\circ}$ for a counting time of typically $60 \mathrm{~s}$ using the digital ALV correlator software. In dynamic light scattering (DLS), the relaxation 
time distribution was obtained using CONTIN analysis of the autocorrelation function $\left(\mathrm{g}^{(2)}-1\right){ }^{58}$ In static light scattering (SLS), the scattering intensity was correlated by the solvent signal and normalized by the toluene signal. The scattering volume change with the scattering angle was also taken into account.

The UV-dimerization of the $\mathrm{CoumC}_{11}-\mathrm{POx}_{\mathrm{n}}$ was performed in a cylindrical photochemical reactor "Rayonnet" composed of 16 symmetrically placed lamps with emission maxima in two different ranges: $254 \mathrm{~nm}(\mathrm{UV}-\mathrm{C})$ and $300 \mathrm{~nm}(\mathrm{UV}-\mathrm{B})$. The samples were irradiated in quartz cuvettes $(1 \mathrm{~cm} \times 1 \mathrm{~cm} \times 4.5$ cm) placed on a circular rotating holder. UV-visible analyses were conducted with a Perkin Elmer lambda 35 UV/Vis spectrometer equipped with PTP-1+1 Peltier System. Atomic Force Microscopy (AFM) was carried out using Innova ${ }^{\mathrm{TM}}$ (Bruker). Sample preparation was done as follows: silica wafers were thoroughly washed with Milli-Q water, acetone and then fuming nitric acid for $2 \mathrm{~h}$. They were subsequently rinsed with Milli-Q water and acetone. Then, the aqueous copolymer suspensions at $0.08 \mathrm{mg} \mathrm{mL}^{-1}$ were successively filtered through 0.45 and then $0.1 \mu \mathrm{m}$ hydrophilic PTFE syringe filter (from Millipore and Whatman, respectively) and $50 \mu \mathrm{L}$ were dropped onto silica wafers which were allowed to dry for 4 days in an exicator under static vacuum in the presence of silica gel. In the case of samples analyzed after UV irradiation, $4 \mathrm{mg} \mathrm{mL}^{-1}$ aqueous copolymer suspensions were successively filtered through 0.45 and then $0.1 \mu \mathrm{m}$ hydrophilic PTFE syringe filter (from Millipore and Whatman), irradiated for $1 \mathrm{~h}$ under a wavelength of $300 \mathrm{~nm}$ using a "Rayonnet" apparatus, diluted 50 times and $50 \mu \mathrm{L}$ were dropped onto silica wafers. Topography and phase signal images were recorded with a resolution of $512 \times 512$ data points. Images were obtained in tapping mode using silicon tips with a spring constant of $48 \mathrm{~N} \mathrm{~m}^{-1}$ and a resonance frequency of approximately $190 \mathrm{kHz}$ (Vista Probes, Phoenix, USA). The images were processed in Gwyddion open source software.

\section{Synthesis of $\mathrm{CoumOH}$}

7-Hydroxy-4-methylcoumarin, $\mathrm{K}_{2} \mathrm{CO}_{3}$ (0.7 eq.) and 11-bromoundecanol (1.4 eq.) were dissolved in ethanol $(0.25 \mathrm{M})$. The mixture was heated at $85{ }^{\circ} \mathrm{C}$ for $20 \mathrm{~h}$ before being cooled and precipitated in diethyl ether. The crude product was filtered, dried under vacuum and recrystallized from ethanol. After filtration and drying under vacuum, a white powder was obtained in $75 \%$ yield.

${ }^{1} \mathrm{H}$ NMR $\left(300 \mathrm{MHz}, \mathrm{CDCl}_{3}\right), \delta=7.4\left(\mathrm{~d}, 1 \mathrm{H}, \mathrm{H}_{2}\right), 6.8\left(\mathrm{~d}, 1 \mathrm{H}, \mathrm{H}_{7}\right), 6.7\left(\mathrm{~s}, 1 \mathrm{H}, \mathrm{H}_{9}\right), 6.1\left(\mathrm{~s}, 1 \mathrm{H}, \mathrm{H}_{6}\right), 3.9(\mathrm{t}$, $\left.2 \mathrm{H}, \mathrm{H}_{11}\right), 3.6\left(\mathrm{~m}, 2 \mathrm{H}, \mathrm{H}_{21}\right), 2.3\left(\mathrm{~s}, 3 \mathrm{H}, \mathrm{H}_{4}\right), 1.8\left(\mathrm{~m}, 2 \mathrm{H}, \mathrm{H}_{12}\right), 1.5-1.2\left(\mathrm{~m}, 16 \mathrm{H}, \mathrm{H}_{13}-\mathrm{H}_{20}\right)$. 
To a solution containing lauryl alcohol or stearyl alcohol in presence of 2 eq. of pyridine dissolved in chloroform $(0.5 \mathrm{M})$, was added dropwise at $0^{\circ} \mathrm{C}$ and left at room temperature during $24 \mathrm{~h}$ a solution of $p$ toluenesulfonyle chloride $(\mathrm{TsCl})$ in chloroform $(0.5 \mathrm{M})$. The mixture was washed with water $(3 \mathrm{x})$, and saturated $\mathrm{Cu}\left(\mathrm{SO}_{4}\right)_{2}$ solution, dried over anhydrous $\mathrm{MgSO}_{4}$, filtered, and evaporated under reduced pressure to yield a white powder (65\% in $\mathrm{C}_{12}$-OTs and $70 \%$ in $\mathrm{C}_{18}$-OTs).

${ }^{1} \mathrm{H}$ NMR $\left(300 \mathrm{MHz}, \mathrm{CDCl}_{3}\right), \delta=7.8\left(\mathrm{~d}, 2 \mathrm{H}, \mathrm{CH}_{\text {aroTs }}\right), 7.25\left(2 \mathrm{H}, \mathrm{CH}_{\text {aroTs }}\right), 3.9\left(\mathrm{~m}, 2 \mathrm{H}, \mathrm{CH}_{2}-\mathrm{OTs}\right), 2.3(\mathrm{~s}$, $\left.3 \mathrm{H}, \mathrm{CH}_{3 \mathrm{Ts}}\right), 1.8-1.1$ ( $\mathrm{m}, 15$ or $23 \mathrm{H}, \mathrm{CH}_{2}$ and $\left.\mathrm{CH}_{3 \text { terminal }}\right)$.

\section{Tosylation of CoumOH: CoumOTs}

A chloroform solution $(1 \mathrm{M})$ of $\mathrm{TsCl}(1.5$ eq. $)$ was added dropwise at $0^{\circ} \mathrm{C}$ to a chloroform solution $(1 \mathrm{M})$ of CoumOH and pyridine ( 2 eq.). The resulting solution was stirred at RT for $24 \mathrm{~h}$, filtered and washed with brine (3x). The organic phase was dried over anhydrous $\mathrm{MgSO}_{4}$ and concentrated under reduced pressure. A recrystallization from diethyl ether gave a white powder in $60 \%$ yield.

${ }^{1} \mathrm{H}$ NMR $\left(300 \mathrm{MHz}, \mathrm{CDCl}_{3}\right), \delta=7.8\left(\mathrm{~d}, 2 \mathrm{H}, \mathrm{CH}_{\text {aroTs }}\right), 7.4\left(\mathrm{~d}, 1 \mathrm{H}, \mathrm{H}_{2}\right), 7.25\left(2 \mathrm{H}, \mathrm{CH}_{\text {aroTs }}\right), 6.8-6.7(\mathrm{~m}, 2 \mathrm{H}$, $\mathrm{H}_{7}$ and $\mathrm{H}_{9}$ ), 6.1 (s, $\left.1 \mathrm{H}, \mathrm{H}_{6}\right), 3.9$ (m, 2H, $\left.\mathrm{CH}_{2}-\mathrm{O}-\right), 3.5$ (m, 4H, $\mathrm{H}_{11}$ and $\left.\mathrm{H}_{21}\right), 2.35$ (s, 3H, $\mathrm{CH}_{3 \mathrm{Ts}}$ ), 2.3 (s, $\left.3 \mathrm{H}, \mathrm{H}_{4}\right), 1.8\left(\mathrm{~m}, 2 \mathrm{H}, \mathrm{H}_{12}\right), 1.5-1.2\left(\mathrm{~m}, 16 \mathrm{H}, \mathrm{H}_{13}-\mathrm{H}_{20}\right)$.

$\mathrm{m}_{\mathrm{p}}=62^{\circ} \mathrm{C}$

\section{Typical procedure of cationic Ring-Opening Polymerization (CROP) of MOx}

Polymerizations were carried out under a dry nitrogen atmosphere. The initiator and MOx, according to $[\mathrm{M}]_{0} /\left[\mathrm{I}_{0}\right.$, were dissolved in dry acetonitrile $(4 \mathrm{M})$. The solution was vigorously stirred at $80{ }^{\circ} \mathrm{C}$ for $15 \mathrm{~h}$. The product was quenched by addition of an adequate amount of methanolic potassium hydroxide ( 5 eq., $5 \mathrm{M}$ ). The flask was maintained at $30{ }^{\circ} \mathrm{C}$ for $4 \mathrm{~h}$. After cooling, the polymer was isolated by slow precipitation from cold diethylether.

$\mathrm{C}_{12}-\mathrm{POx}_{\mathrm{n}}:{ }^{1} \mathrm{H}$ NMR $\left(300 \mathrm{MHz}, \mathrm{CDCl}_{3}\right), \delta=3.7-3.2\left(\mathrm{~m},(4 \mathrm{n}+2) \mathrm{H}, \mathrm{CH}_{2}\right.$ POx and $\left.\mathrm{CH}_{2} \mathrm{~N}_{\text {alkyl chain }}\right), 2.4-2.1(\mathrm{~m}$, 3n, $\mathrm{CH}_{3}$ POx $), 1.3$ (m, 20H, $\mathrm{CH}_{2}$ aliphatic), 0.9 (t, 3H, $\mathrm{CH}_{3}$ aliphatic). $\mathrm{M}_{\mathrm{n}}$, yield: $1210 \mathrm{~g} \mathrm{~mol}^{-1}, 51 \% ; 2440 \mathrm{~g} \mathrm{~mol}^{-1}, 57 \% ; 2880 \mathrm{~g} \mathrm{~mol}^{-1}, 69 \%$.

$\mathrm{C}_{18}-\mathrm{POx}_{\mathrm{n}}:{ }^{1} \mathrm{H} \mathrm{NMR}\left(300 \mathrm{MHz}, \mathrm{CDCl}_{3}\right), \delta=3.7-3.2\left(\mathrm{~m},(4 \mathrm{n}+2) \mathrm{H}, \mathrm{CH}_{2}\right.$ POx and $\left.\mathrm{CH}_{2} \mathrm{~N}_{\text {alkyl chain }}\right), 2.4-2.1(\mathrm{~m}$, $3 \mathrm{n}, \mathrm{CH}_{3}$ POx $), 1.3$ (m, 32H, $\mathrm{CH}_{2}$ aliphatic), 0.9 (t, $3 \mathrm{H}, \mathrm{CH}_{3}$ aliphatic).

$\mathrm{M}_{\mathrm{n}}$, yield: $3330 \mathrm{~g} \mathrm{~mol}^{-1}, 63 \%$. 
$\mathrm{C}_{\text {oum }} \mathrm{C}_{11}-\mathrm{POx}_{\mathrm{n}}:{ }^{1} \mathrm{H}$ NMR $\left(300 \mathrm{MHz}, \mathrm{CDCl}_{3}\right), \delta=7.4\left(\mathrm{~d}, 1 \mathrm{H}, \mathrm{H}_{2}\right), 6.8\left(\mathrm{~d}, 1 \mathrm{H}, \mathrm{H}_{7}\right), 6.7\left(\mathrm{~s}, 1 \mathrm{H}, \mathrm{H}_{9}\right), 6.1$ (s, $\left.1 \mathrm{H}, \mathrm{H}_{6}\right), 4.2\left(\mathrm{~m}, 2 \mathrm{H}, \mathrm{H}_{21}\right), 3.9\left(\mathrm{t}, 2 \mathrm{H}, \mathrm{H}_{11}\right), 3.7\left(\mathrm{~m}, 2 \mathrm{H}, \mathrm{H}_{\mathrm{b}^{\prime}}\right), 3.5-3.25\left(\mathrm{~m},(2 \mathrm{n}-2) \mathrm{H}, \mathrm{H}_{\mathrm{a}}\right.$ and $\left.\mathrm{H}_{\mathrm{b}}\right), 3.2(\mathrm{~m}, 2 \mathrm{H}$, $\left.\mathrm{H}_{\mathrm{a}^{\prime}}\right), 2.25\left(\mathrm{~s}, 3 \mathrm{H}, \mathrm{H}_{4}\right), 2.2\left(\mathrm{~s}, 3 \mathrm{H}, \mathrm{H}_{\mathrm{d}^{\prime}}\right), 2.2-1.75\left(\mathrm{~m},(\mathrm{n}-1) \mathrm{H}, \mathrm{H}_{\mathrm{d}}\right), 1.75\left(\mathrm{~m}, 2 \mathrm{H}, \mathrm{H}_{12}\right), 1.5-1.2\left(\mathrm{~m}, 16 \mathrm{H}, \mathrm{H}_{13^{-}}\right.$ $\mathrm{H}_{20}$ ).

$\mathrm{M}_{\mathrm{n}}$, yield: $1050 \mathrm{~g} \mathrm{~mol}^{-1}, 45 \% ; 2140 \mathrm{~g} \mathrm{~mol}^{-1}, 42 \% ; 2900 \mathrm{~g} \mathrm{~mol}^{-1}, 62 \%$. 


\section{Conclusions}

An efficient synthetic route to photo-active amphiphilic polyoxazolines decorated by coumarin end group, CoumC $_{11}-\mathrm{POx}_{\mathrm{n}}$, was described. The hydrophobic block CoumC $\mathrm{C}_{11}$ amounts to $\mathrm{C}_{16}$ alkyl chain, intermediate between $\mathrm{C}_{12}-\mathrm{POx}_{\mathrm{n}}$ and $\mathrm{C}_{18}-\mathrm{POx}_{\mathrm{n}}$. Similarly to $\mathrm{C}_{\mathrm{m}}-\mathrm{POx}_{\mathrm{n}}$, CoumC $\mathrm{C}_{11}-\mathrm{POx}_{\mathrm{n}}$ self-organized in water into spherical nanoparticles with $\mathrm{D}_{\mathrm{H}}$-values around $10 \mathrm{~nm}$. As observed with photo-crosslinkable copolymers, the UV-irradiation of photo-dimerizable copolymers CoumC $\mathrm{C}_{11}-\mathrm{POx}_{\mathrm{n}}$ preserved the size of the nanoparticles. This study demonstrated that the linear amphiphilic copolymers constitute a promising alternative route to the graft copolymers for photo-active polymeric systems and the advantages were discussed. The response of the inner compartment of the nanoparticles indiscriminately occurred by photo-crosslinking of graft copolymers bearing pendant coumarin units or by photo-dimerization of linear polymers bearing terminal coumarin unit.

\section{Acknowledgements}

The authors thank the "Ministère de l'Enseignement Supérieur et de la Recherche", the "Centre National de la Recherche Scientifique", Institut Carnot Polynat and Labex Arcane (ANR-11-LABX-0003-01).for financial support. They are thankful to Aurélien Lebrun at the "Laboratoire de Mesures Physiques" in University of Montpellier and Isabelle Jeacomine at the "Centre de recherche sur les macromolécules végétales" for ${ }^{1} \mathrm{H}$ DOSY NMR. The authors acknowledge Dr. Frédéric Dubreuil, Carolina Noronha and Tiffany Gomez for AFM imaging, and Philippe Colin-Morel for dn/dC measurement. 


\section{Notes and references}

a Institut Charles Gerhardt Montpellier UMR5253 CNRS-UM-ENSCM, Equipe Ingénierie et Architectures Macromoléculaires, Université Montpellier - Bâtiment 17 - cc1702, Place Eugène Bataillon, F-34095 Montpellier cedex 5, France

${ }^{b}$ Université Grenoble Alpes, CERMAV, F-38000 Grenoble, France

${ }^{c}$ CNRS, CERMAV, F-38000 Grenoble cedex 9, France.

Electronic Supplementary Information (ESI) available: [details of any supplementary information available should be included here]. See DOI: 10.1039/b000000x/

1. Y. Mai and A. Eisenberg, Chemical Society Reviews, 2012, 41, 5969-5985.

2. T. P. Lodge, Macromolecular Chemistry and Physics, 2003, 204, 265-273.

3. C. Bouilhac, E. Cloutet, D. Taton, A. Deffieux, R. Borsali and H. Cramail, Journal of Polymer Science Part A: Polymer Chemistry, 2009, 47, 197-209.

4. C. Bouilhac, E. Cloutet, D. Taton, A. Deffieux, R. Borsali and H. Cramail, Macromolecules, 2008, 41, 7321-7329.

5. C. Giacomelli, V. Schmidt, K. Aissou and R. Borsali, Langmuir, 2010, 26, 15734-15744.

6. C. Travelet, C. Bouilhac, J.-J. Robin and R. Borsali, Soft Matter, 2014, 10, 7545-7557.

7. Photochemistry and Photophysics of Polymer Materials, N. S. Allen, John Wiley \& Sons, Inc, 2010.

8. S. Chatani, C. J. Kloxin and C. N. Bowman, Polymer Chemistry, 2014, 5, 2187-2201.

9. L. Fertier, H. Koleilat, M. Stemmelen, O. Giani, C. Joly-Duhamel, V. Lapinte and J. J. Robin, Progress in Polymer Science, 2013, 38, 932-962.

10. E. S. Read and S. P. Armes, Chemical Communications, 2007, 29, 3021-3035.

11. Y. Zhao, Macromolecules, 2012, 45, 3647-3657.

12. Y. Zhao, Journal of Materials Chemistry, 2009, 19, 4887-4895.

13. J. Jiang, B. Qi, M. Lepage and Y. Zhao, Macromolecules, 2007, 40, 790-792.

14. K. B. Thurmond, H. Huang, C. G. Clark, T. Kowalewski and K. L. Wooley, Colloids and Surfaces B, 1999, 16, 45-54.

15. M. G. Mohamed, K.-C. Hsu and S.-W. Kuo, Polymer Chemistry, 2015, 6, 2423-2433.

16. Q. Zhang, N. Re Ko and J. Kwon Oh, Chemical Communications, 2012, 48, 7542-7552. 
17. R. H. Huyck, S. R. Trenor, B. J. Love and T. E. Long, Journal of Macromolecular Science, 2008, 40, 9-15.

18. J. Lee, M. V. S. N. Maddipatla, A. Joy and B. D. Vogt, Macromolecules, 2014, 47, 28912898.

19. W. Fan, X. Tong, Q. Yan, S. Fu and Y. Zhao, Chemical Communications, 2014, 50, 1349213494.

20. S. R. Trenor, T. E. Long and B. J. Love, Macromolecular Chemistry and Physics, 2004, 205, 715-723.

21. Y. Shi, R. M. Cardoso, C. F. van Nostrum and W. E. Hennink, Polymer Chemistry, 2015, 6, 2048-2053.

22. Q. Bian, Y. Xiao, C. Zhou and M. Lang, Journal of Colloid and Interface Science, 2013, 392, 141-150.

23. Y. Li, Y. Tang, K. Yang, X. Chen, L. Lu and Y. Cai, Macromolecules, 2008, 41, 4597-4606.

24. J. S. Kim and J. H. Youk, Polymer, 2009, 50, 2204-2208.

25. D. Roy and B. S. Sumerlin, Macromolecular Rapid Communications, 2014, 35, 174-179.

26. J.-F. Gohy and Y. Zhao, Chemical Society Reviews, 2013, 42, 7117-7129.

27. G. Kaur, P. Johnston and K. Saito, Polymer Chemistry, 2014, 5, 2171-2186.

28. T. Tanaka, T. Kumamoto and T. Ishikawa, Tetrahedron Letters, 2000, 41, 10229-10232.

29. M. Suzuki, Y. Li, P. C. Smith, J. A. Swenberg, D. E. Martin, S. L. Morris-Natschke and K.H. Lee, Medicinal Research Reviews, 2003, 23, 322-345.

30. M. A. Musa, J. S. Cooperwood and M. O. F. Khan, Current Medicinal Chemistry, 2008, 15, 2664-2679.

31. S. R. Trenor, A. R. Shultz, B. J. Love and T. E. Long, Chemical Review, 2004, 104, 30593078.

32. Gangadhara and K. Kishore, Macromolecules, 1995, 28, 806-815.

33. J. Fang, C. Whitaker, B. Weslowski, M.-S. Chen, J. Naciri and R. Shashidhar, Journal of Materials Chemistry, 2001, 11, 2992-2995.

34. H.-C. Lin, K.-W. Lee, C.-M. Tsai and K.-H. Wei, Macromolecules, 2006, 39, 3808-3816.

35. J. Serin, X. Schultze, A. Adronov and J. M. J. Fréchet, Macromolecules, 2002, 35, 53965404.

36. H. Lin, X. Wan, Z. Li, X. Jiang, Q. Wang and J. Yin, ACS Applied Materials \& Interface, 2010, 2, 2076-2082. 
37. R. Hoogenboom and H. Schlaad, Polymers, 2011, 3, 467-488.

38. R. Hoogenboom, Angewandte Chemie-International Edition, 2009, 48, 7978-7994.

39. D. Rayeroux, V. Lapinte and P. Lacroix-Desmazes, Journal of Polymer Science Part A: Polymer Chemistry, 2012, 50, 4589-4593.

40. B. Guillerm, S. Monge, V. Lapinte and J.-J. Robin, Journal of Polymer Science Part A: Polymer Chemistry, 2013, 51, 1118-1128.

41. C. Weber, M. Wagner, D. Baykal, S. Hoeppener, R. M. Paulus, G. Festag, E. Altuntas, F. H. Schacher and U. S. Schubert, Macromolecules, 2013, 46, 5107-5116.

42. B. Guillerm, V. Darcos, V. Lapinte, S. Monge, J. Coudane and J.-J. Robin, Chemical Communications, 2012, 48, 2879-2881.

43. C. Alexis, C. Charnay, V. Lapinte and J.-J. Robin, Progress in Organic Coatings, 2013, 76, 519-524.

44. B. Guillerm, S. Monge, V. Lapinte and J.-J. Robin, Macromolecules, 2010, 43, 5964-5970.

45. B. Guillerm, S. Monge, V. Lapinte and J.-J. Robin, Macromolecular Rapid Communications, 2012, 33, 1600-1612.

46. C. Giardi, V. Lapinte, C. Charnay and J.-J. Robin, Reactive and Functional Polymers, 2009, 69, 643-649.

47. C. Giardi, V. Lapinte, F. Nielloud, J.-M. Devoisselle and J.-J. Robin, Journal of Polymer Science Part A: Polymer Chemistry, 2010, 48, 4027-4035.

48. M. Stemmelen, C. Travelet, V. Lapinte, R. Borsali and J.-J. Robin, Polymer Chemistry, 2013, 4, 1445-1458.

49. C. Travelet, M. Stemmelen, V. Lapinte, F. Dubreuil, J.-J. Robin and R. Borsali, Journal of Nanoparticle Research, 2013, 15, 1626-1641.

50. G. David and A. Ioanid, Journal of Applied Polymer Science, 2001, 80, 2191-2199.

51. T. R. Dargaville, R. Forster, B. L. Farrugia, K. Kempe, L. Voorhaar, U. S. Schubert and R. Hoogenboom, Macromolecular Rapid Communications, 2012, 33, 1695-1700.

52. Y. Chujo, K. Sada, R. Nomura, A. Naka and T. Saegusa, Macromolecules, 1993, 26, 56115614.

53. Y. Chujo, K. Sada, A. Naka, R. Nomura and T. Saegusa, Macromolecules, 1993, 26, 883-887.

54. Y. Chujo, K. Sada and T. Saegusa, Macromolecules, 1990, 23, 2693-2697.

55. G. Volet, L. Auvray and C. Amiel, Journal of Physical Chemistry B, 2009, 113, 1353613544. 
56. R. Obeid, E. Maltseva, A. F. Thünemann, F. Tanaka and F. M. Winnik, Macromolecules, 2009, 42, 2204-2214.

57. G. Volet, L. Auvray and C. Amiel, Macromolecules, 2005, 38, 5190-5197.

58. S. W. Provencher, Die Makromolekulare Chemie, 1979, 180, 201-209.

59. A. G. Dal Bó, V. Soldi, F. C. Giacomelli, C. Travelet, B. Jean, I. Pignot-Paintrand, R. Borsali and S. Fort, Langmuir, 2012, 28, 1418-1426.

60. K.-F. Arndt and G. Müller, Polymercharakterisierung, Hanser, Munich, 1996 Germany (in German).

61. P. Cifra and T. Bleha, Macromolecular Theory and Simulations, 2007, 16, 501-512.

62. T. Norisuye, Progress in Polymer Science, 1993, 18, 543-584.

63. P. Ball, Designing the molecular world: chemistry at the frontier. Princeton University Press, Princeton (USA) 1994.

64. A. Macchioni, G. Ciancaleoni, C. Zuccaccia and D. Zuccaccia, Chemical Society Reviews, 2008, 37, 479-489.

65. C. Travelet, G. Schlatter, P. Hébraud, C. Brochon, A. Lapp and G. Hadziioannou, Langmuir, 2009, 25, 8723-8734.

66. C. Bouilhac, C. Travelet, A. Graillot, S. Monge, R. Borsali and J.-J. Robin, Polymer Chemistry, 2014, 5, 2756-2767.

67. K. Yoshida, N. Matubayasi and M. Nakahara, Journal of Chemical Physics, 2008, 129, 214501.

68. K. Loos, A. Böker, H. Zettl, M. Zhang, G. Krausch and A. H. E. Müller, Macromolecules, 2005, 38, 873-879. 